№ 8; Т. 155. № 9; Брикнер А.Г. Путешествие императрицы Екатерины ІІ-й в Крым // Исторический вестник. 1885. Т. 21. С. 5-23, 242-264, 444-509; Muтрофанов П.П. Политическая деятельность Иосифа II, ее сторонники и ее враги 1780-1790. СПб., 1907; Бессарабова Н.В. Иосиф II и Екатерина II в путешествиях по России // Немцы в России: Российско-немецкий диалог. СПб., 2001; Петрова М.А. Переписка Екатерины II и Иосифа II как исторический источник // Источниковедческие исследования: Сб. ст. М., 2004. Вып. 2. С. 167-194.

3 Петрова М.А. Екатерина II и Иосиф II. Формирование российско-австрийского союза 1780-1790. М., 2011.

4 Molnár J. Magyar Könyvház. VIII. sz. 100-101; Kalatay Ferencz (Xaver) // Szinynyei J. Magyar írók élete és munkái. 5. kötet. Budapest, 1897. 814-815. old.

${ }^{5}$ CM.: Szinnyei J. Magyar írók élete és munkái. 815. old.

6 Ponori Thewrewk M. Franciscus Xaverius Kalataynak, Praepost' Báró Rewiczky Urhoz, Löwenbergből datalt és kűldött Levele; mellyben, néhai b.e. II. József Császár' és Király' 1780 Eszendőbéli, Muszka Országba tett útazását írja // Tudományos Gyújtemény. Pest, 1823. X. köt. 27-36. old.

7 CM.: Szinnyei J. Magyar írók élete és munkái. 815. old.

8 Kaposvári Gy. Útinapló II. József császár Kijev-Moszkva-Leningrád-i [sic!] utazásáról // Jászkunság. 1959 (március). 5. évf. 1. sz. 36-39. old.

9 Ibid. 39. old.

\title{
K вопросу
}

- праве владения оружием христианами Османской империи (на материалах наследственных описей г. Софии в XVIII - начале XIX вв.)*

В Османской империи право носить оружие имели лишь лица, состоявшие на государственной службе, курьеры губернаторов и других крупных чиновников; во время разъездов они имели при себе саблю или пистолет, иногда сабля заменялась ятаганом. Однако, по воспоминаниям секретаря российского генерального консула в Смирне в 1830-х гг., оружие в империи было достаточно распространено: «По-

* Публикация подготовлена при финансовой поддержке РФФИ в рамках проекта № 18-59-18002 Болг_а. 
скольку оружие разрешено иметь в дороге, погонщики, все находящиеся в пути, а иногда и земледельцы, идущие на работу, могут быть вооружены. Самое употребительное оружие в народе - ятаган и пистолеты. Кинжалов нигде не видно; иногда за поясом носят большой нож, который необходим для каждого, так как за столом ножи не подают. Люди почтенные имеют только саблю, иногда пистолеты за поясом. Ружье в дороге несет за ними слуга» ${ }^{1}$.

В наследственных протоколах кадийских судов оружие, как огнестрельное, так и холодное, упоминается часто. Источник позволяет определить время появления и распространения в болгарских землях тех или иных его видов, стоимость и назначение, а также сравнить условия владения оружием мусульманами и христианами.

Упоминание оружия в наследственных протоколах мусульман встречается чаще, чем в протоколах христиан. Это можно объяснить тем, что, по законам шариата, неверным, живущим на завоеванных мусульманами землях, носить оружие было запрещено ${ }^{2}$. Коренным образом ситуация изменилась, когда в ходе так называемой «Кырджалийской смуты» (1779-1813 гг.) простому населению, в том числе немусульманам, было впервые разрешено иметь оружие для самозащиты, поскольку официальные власти были не в состоянии противостоять разбойникам. По оценкам болгарских историков, это разрешение способствовало росту самоорганизации среди болгар - впервые за несколько столетий османской власти болгары, обладая оружием, получили возможность самостоятельно обороняться ${ }^{3}$.

Предметы вооружения, упомянутые в наследственных описях жителей г. Софии, разнообразны. Среди холодного оружия это различные виды сабель, ятаганы, реже кинжалы. Из огнестрельного оружия известны пистолеты, ружья и «пушки» - оружие для охоты. В описях имущества христиан холодное оружие не упоминается: они владели только ружьями и пистолетами.

Впервые пистолет, принадлежащий вопреки официальному запрету, христианину, упомянут в протоколе о наслед- 
стве плотника Стедана (1731 г. $)^{4}$. Он оценен в 45 акче, и эта цена невелика: так, в 60 акче оценены пять старых подушек, в 15 акче - топор. Всего опись имущества Стефана содержит 15 пунктов (включая дом и набор плотницких инструментов) общей стоимостью 4755 акче.

Целый арсенал огнестрельного оружия представлен в наследственном протоколе суконщика Йована $\left(1798\right.$ г.) ${ }^{5}$, в нем числятся три пистолета общей стоимостью 10 курушей, три ружья - 15 курушей и «ружье и мелочи» - один куруш. «Мелочи» нередко встречаются в описях имущества - под этим словом подразумеваются несущественные предметы, перечислять и оценивать каждый из которых по отдельности, как считали составители, нецелесообразно.

В наследственном протоколе священника Анастаса (1790 г.) упомянуты две пары пистолетов общей стоимостью восемь курушей 6 . Такая цена за четыре пистолета невелика, а Анастас - единственный священник, в описи имущества которого присутствует оружие. Он производит впечатление достаточно состоятельного человека: в описи его имущества присутствуют собрание книг, золотые украшения, множество серебряных изделий.

Огнестрельное оружие, принадлежавшее мусульманам, более разнообразно; пистолеты и ружья в их протоколах нередко богато декорированы, украшены серебром и, несомненно, являются статусной вещью. С середины XVIII в. дорогое оружие все чаще упоминается в наследственных протоколах.

Серебряные пистолеты упомянуты в наследственной описи Эссеида Мехмеда Ага $\left(1750\right.$ г.) ${ }^{7}$. Он был богат - наряду с огромным числом ценных вещей, ему принадлежали две пары серебряных пистолетов с кобурой, стоимостью 1800 и 4800 акче, что дорого для того времени и сопоставимо со стоимостью небольшого дома.

Еще одна пара посеребренных пистолетов с кобурой стоимостью в 60 курушей (7200 акче) и пистолеты английского производства за 100 курушей (12000 акче) упомянуты в наследственной описи 1809 г. Элхаджа Мустафы Ага 
человек также был состоятелен - помимо этих пистолетов из оружия ему принадлежали: «длинное ружье» за 50 курушей, «два других ружья - 20 курушей», посеребренный патронташ за 30 курушей, и несколько сабель, в том числе посеребренных. Кроме того, в этом протоколе упомянута некая пушка-фрылынта* - вид короткоствольного охотничьего ружья.

Следует отметить, что первое упоминание ружья-фылынта в наследственных описях относится к 1762 г; ее обладателем был Чолак Осман Беше. В его наследственном протоколе данное охотничье ружье оценено в 660 акче, то есть дороже, чем несколько сабель (161 и 120 акче), пара пистолетов (631 акче) и ружье (161 акче).

Со временем ружье-фылынта встречается в наследственных описях все чаще, и цена его становится ниже. Изначально само обладание этим видом оружия можно считать одним из показателей высокого статуса ее владельца. Позднее в наследственных протоколах богатых людей начинают появляться пушки-фылынта с золотой отделкой ${ }^{10}$.

K началу XIX в. чаще упоминаются также посеребренные пистолеты и ружья, оружие с рукоятками, декорированными золотом, серебром и перламутром.

Холодное оружие фригурирует практически в каждом документе, посвященном рассмотрению наследства мусульман. Чаще всего встречаются различные виды сабель, являвшихся самым дешевым оружием - ими владели даже бедные горожане. Нередко в документах они фриксируются с определением «старая» и стоят дешево. Так, в наследстве брадобрея Абди (1814 г.) ${ }^{11}$, который судя по документу, был небогатым человеком, упомянуто две старых сабли общей стоимостью всего в два куруша и 21 пара́. Комплект пистолетов в этом протоколе оценивается в 24 куруша, упомянутый также ятаган - в 56 курушей.

Ятаган - клинковое холодное оружие, клинок которого имеет двойной изгиб, позволяющий наносить режущий

\footnotetext{
* от англ. flint - кремень, flint-lock - кремневое ружье.
} 
и колющий удары. Их массовое производство в Османской империи относится к периоду не ранее второй половины XVIII в. ${ }^{12}$ В наследственных описях жителей Софрии ятаганы встречаются относительно редко и появляются только в XIX в. Первое упоминание их относится к 1814 г. - в протоколе сапожника Хасана ${ }^{13}$, довольно состоятельного человека, ятаган оценен в 23 куруша (для сравнения пистолет в кобуре оценен в 16 курушей). Также к 1814 г. относятся еще три упоминания ятаганов. Их владельцы различны по социальному положению, а стоимость варьируется от семи до 56 курушей.

Реже всего из холодного оружия в наследственных описях фиигрирует гаддаре - турецкая сабля XVII в. с малоизогнутым широким и тонким клинком ${ }^{14}$. Этот вид оружия упоминается в наследственных описях всего дважды - в 1750 и 1809 гг. В обоих случаях его хозяевами являются очень богатые люди. Так, в 1750 г. гаддаре упомянуто в наследственном протоколе силяхдара Эссеида Мехмеда Ага, общее состояние которого составляло 1395256 акче ${ }^{15}$. Собрание оружия этого человека роскошно: помимо уже перечисленного, в протоколе упомянуты дамасская сабля с серебряной вставкой, несколько пар посеребренных пистолетов, дорогая конская упряжь, ружья.

Таким образом оружие было неотъемлемой частью жизни мусульманского населения Софии. Упоминание различных его видов практически в каждой имущественной описи вне зависимости от финансового состояния покойного, его социального статуса и рода занятий контрастирует с практически полным отсутствием оружия у христианского населения города. Нельзя не заметить, что если среди мусульман самым распространенным оружием является сабля, то в наследственных протоколах христиан холодное оружие не упоминается вообще, чаще всего из оружия встречается пистолет. Можно заключить, что если для мусульман оружие в XVIII-XIX вв. в большой степени воспринималось как элемент престижа и неотьемлемая часть культуры, то у христиан, будучи редкостью, оружие в первую очередь слу- 
жило по прямому назначению. Также стоит отметить, что вопреки официальному запрету на ношение оружия, владение им фиксировалось в наследственных описях - то есть официальных османских документах, что говорит об относительной условности этого запрета. При этом, несмотря на официальное разрешение со стороны османских властей на ношение христианами оружия, роста его числа в христианской среде в конце XVIII в. не наблюдается. Это позволяет сделать вывод, что тенденция к росту числа вооружения у населения в период Кырджалийской смуты не коснулась крупных городов в столь значительной мере, как в сельских поселениях, о чем пишут исследователи ${ }^{16}$.

\section{Примечания}

1 Цит. по: Аствацатурян Э.Г. Турецкое оружие в собрании Государственного исторического музея. М., 2002. С. 35.

2 Гиргас В. Права христиан на Востоке по мусульманским законам. СПб, 1865. C. 35.

${ }^{3}$ Мутафчиева В. Кърджалийско време // В. Мутафчиева. Избрани произведения. Т. 2. Пловдив, 2008. С. 412-421.

4 ТИБИ. Т. 6. С. 27-28.

5 Там же. С. 133-135.

6 Там же. С. 119-120.

7 Там же. С. 51-56.

8 Там же. С. 149-153.

9 Там же. С. 79-87.

10 Там же. С. 184-191.

11 Там же. С. 191-192.

12 Аствацатурян Э.Г. Турецкое оружие... С. 134.

13 ТИБИ. Т. 6. С. 179-183.

14 Аствацатурян Э.Г. Турецкое оружие... С. 332.

15 ТИБИ. Т. 6. С. 51-56.

16 Лори Б. Разсъждения върху исторические мит «Пет века ни клаха» // Историческо бъдеще. 1997. № 1. С. 92-99; Мутафччева В. Кърджалийско време; она же. Някои расъждения относно расзъжденията на Бернар Лори върху историческия мит «Пет века ни клаха» // Историческо бъдеще, 1997, № 2. C. 75-81. 